\title{
Sven Nilsson i Blendaland
}

\section{Påvel Nicklasson}

\section{Inledning}

En intressant fråga i forskningen om Lundaprofessorn Sven Nilsson (1787-1883) är när och hur han började intressera sig för arkeologi. Nilssons avhandling Den skandinaviska Nordens ur-invånare, utgiven häftesvis mellan 1838 och 1843, anses vara den vetenskapliga arkeologins portalarbete. Den föregicks av en mindre uppsats, Inledning till jagtens och fiskets historia som trycktes 1835 i andraupplagan av hans Fauna, delen om fåglarna. ${ }^{1}$ Det kom som en stor överraskning för samtiden att naturforskaren och zoologen Nilsson intresserade sig för forntiden och det finns egentligen bara antydningar som visar när och hur hans intresse vaknade och det är ett litet mysterium varför Nilsson bestämde sig för att förnya arkeologin.

Om man letar i Nilssons tidiga anteckningsböcker och korrespondens hittar man spridda antikvariska iakttagelser bland alla noggranna naturvetenskapliga observationer. Detta är kanske inte så underligt, en akademiker på Nilssons tid skulle vara allmänbildad och kunna litet om det mesta. Dessa passager kan dock kasta ljus över hur den unge Nilsson såg på forntiden och kanske även på hans väg till arkeologin. Man kan i vissa fall spåra tanketrådar som uppträder tydligare i senare arkeologiska arbeten och studera hur han kommit fram till ställningstaganden. Anteckningarna visar även hur dåtidens antikvarier arbetade med ett brett källmaterial där arkeologi, historia, lingvistik och sagor studerades parallellt och där de moderna disciplinerna ännu inte knoppats av från det samlade antikstudiet.

En samling tidiga antikvariska iakttagelser berör Nilssons resa genom Värend 1821. Reseskildringen, då den sätts in i sitt sammanhang, ger även en antydan om Sven Nilssons minst sagt eldfängda personlighet.

\section{Den odräglige}

Fru Fortunas hjul snurrade 1821 brant uppåt för Sven Nilsson. Han fick på våren professors namn och företräde i Lunds universitets lönetur. Löneturen grundades i att universitet hade ett begränsat antal avlönade professurer. Eftersom det oftast fanns fler professorer än professurer, gick flera professorer oavlönade tills en äldre kollega avgick eller avled. För att administrera detta satte man upp en lönetur, en kölista, på vilken professorerna kunde studera hur länge det i bästa fall dröjde innan de fick betalt. Professorer kunde arbeta utan lön i mer än ett decennium och villkoren för akademiker var ett stort problem.

$1 \quad$ Nilsson 1838-1843; 1835a 
Den nyutnämnde Nilsson trängde sig före flera mer meriterade och äldre professorer, vilket väckte mycket ont blod. Detta var i och för sig inte bara Nilssons fel, utan förturen hade enväldigt beslutats av universitets kansler Lars von Engeström, som styrde och ställde efter eget huvud och vars agerande i många frågor kan liknas vid fiffel. Nilsson hade dock skrivit till Engeström och hotat med att avsluta sina vetenskapliga studier och sadla om till präst om inte Engeström såg till att han fick en trygg inkomst. Nilsson var skicklig då det gällde att ställa sig in hos nyckelpersoner. ${ }^{2}$

Nilsson fick en ordnad ekonomi, vilket givetvis gynnade forskning och livet i övrigt. Som nybliven professor började han också undervisa, en syssla som han inte hade någon naturlig fallenhet för. Hans välgörare kemisten Jöns Jakob Berzelius och Hans Gabriel Trolle Wachtmeister fruktade till och med för Nilssons liv då han släpptes lös på studenterna: ”Om icke innan slutet af hans Rectorat Pojkarne giöra kol på eller af honom så är Guds synnerliga nåd med i spelet. En hel nation, den Götheborgska, är nu i insurrectionstillstånd."3 Att giöra "kol på eller af" Nilsson hade dubbel innebörd eftersom ett av Nilssons stora intressen 1821 var förkolnade växtfossil som han trätte med Berzelius och Trolle Wachtmeister om. De menade att fossilen borde studeras kemisktmineralogiskt, medan Nilsson obönhörligt framförde att det enda sättet att studera dem var med hjälp av den nya vetenskapen, geologi, som Nilsson var en av de tidigaste svenska utövarna av. Trolle Wachtmeister skrev uppgivet till Berzelius att: "Min lilla kemi, kan icke, ehuru liten den är, passas in i hans geologie vid bedömmande af naturens konstgrepp i de här pseudomorphoserna."4

Även om Berzelius och Trolle Wachtmeisters korrespondens innehåller minst sagt syrliga kommentarer om Nilsson och dennes sociala oförmåga, tvekade de inte ett ögonblick över att han var ett geni och att de hade en plikt mot vetenskapen att stötta honom hur illa han än uppförde sig.

Striderna runt Nilsson skulle komma att fortsätta under hela hans liv och han såg sig själv utan skuld till de ständiga konflikterna. Han sade bara Sanningen och hade alltid rätt och det var inte hans fel att omgivningen hade svårt att acceptera detta enkla faktum. År 1841 skrev han till Berzelius om sanningssägarens svåra situation vid Lunds universitet:

Man huttlas, trakasseras, förföljes för det man gör sin skyldighet och är nitisk i sitt kall, och mot denna hånande förföljelse har man platt intet försvar. Denna anarchiska lamhet och deraf nödvändigt följande oförsynthet griper kring sig ända ned bland studenthopen, och snart blir det odrägligt att ha närmare bestyr med den. ${ }^{5}$

År 1821 snurrade som sagt fru Fortunas hjul brant uppåt och förutom professuren fick Nilsson ett resestipendium för en längre resa genom Sverige. Han kom så långt norrut

2 För biografiska uppgifter om Nilsson och hans mångfacetterade akademiska karriär, se artiklar i Regnéll 1983a.

3 Trolle Wachtmeister till Berzelius 2 mars 1821. Citerat i Trofast 2002, s 168

4 Trolle Wachtmeister till Berzelius 2 mars 1821. Citerat i Trofast 2002, s 168

5 Nilsson till Berzelius 29 maj 1841. Citerat i: Berzelius 1932, s 177ff 
som till Uppsala, där han skaffade sig nya ovänner genom att bland annat avfärda professor Wahlenberg då han visade Nilsson Vetenskaps-Societetens samlingar och som enligt Nilsson "smädande visa aftryck af snäckor såsom ormar från Indien och ett kritstycke från Limhamn som ett Rhinoceroshorn Jag tog min hatt och gick ungefär med

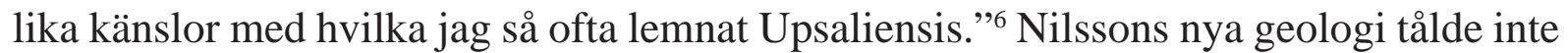
att fossil behandlades som gammal kuriosa.

\section{Blendaland}

För att ta sig till Uppsala var Nilsson tvungen att passera Värend, skådeplats för den runt 1820 mycket populära Blendalegenden. Det kan ifrågasättas om legenden är ett autentiskt minne från forntiden. Olle Ekstedt har skrivit en översikt över legendens tillkomst, varianter och vindlingar. ${ }^{7}$ Legenden skapades på 1600-talet av Petter Rudbeck (1660-1709) utifrån lokala sägner, lån från äldre källor och en fritt flödande fantasi och han broderade ut berättelsen våldsamt. Fantasin fanns i generna, Petter Rudbeck var brorson till den kände Uppsalaprofessorn Olof Rudbeck och skrev i samma fantastiska anda då han framhävde sin hemtrakt, Värend. Enligt Rudbeck skulle Blenda ha levt på 1400-talet före Kristus. Dateringen byggde på Bibeln, den tid som vi kallar bronsålder och är helt uppåt väggarna.

För den som inte har Blendalegenden aktuell handlar den om den tappra småländska vikingakvinnan Blenda eller Blända. När de småländska männen någon gång under forntiden, eller medeltiden, var ute i viking, drabbades Småland av hemsökelse i form av härjande danska vikingar. Utan krigare låg landet utlämnat. Då trädde Blenda fram. Tillsammans med de andra kvinnorna dukade hon fram mat och dryck på en hed. Därefter skickade de bud till danskarna att de skulle ge sig till dem eftersom deras män var borta. Danskarna begav sig förväntansfulla till heden och Magnus Bruzelius (17861855) berättar vad som därefter hände:

När de om aftonen kommo dit, funno de borden dukade och uppfyllde med kostelig mat och dryck; men Blända hade med sin här dragit sig in i skogen. Danskarna trodde då, att qwinnorna hade flytt bort af häpenhet och hade icke wågat uthärda deras åsyn. De satte sig derföre genast att äta och dricka och lade sig sedan öfwer hela fältet att sofwa. Då det hade lidit något öfwer midnatten, kom Blända fram ur skogen med hela sin här, som war bewäpnad med yxor och stänger. De öfwerföllo då de Danske och nedergjorde dem alla, så att ingen skall hafwa kommit tillbaka, som kunnat berätta om detta slag. ${ }^{8}$

Gästabudet var en lömsk krigslist och resulterade i en episk danskslakt. Maten skulle ha dukats på en plats som antikvarierna grälade om skulle kallas för Blendas hed eller Bråvalla hed. Blendas hed knöt platsen till sagan, men var för övrigt anonymt. Bråvalla hed knöt platsen till ett större sagohistoriskt sammanhang men fick konkurrens av Brå-

$6 \quad$ LUB C5 p 51-52; Regnéll 1983b s 30

7 Ekstedt 1987, s 115f, $126 f$

8 Bruzelius 1821, 28f 
viken i Östergötland. Många fornlämningar i Värend blev spår efter legenden och i de småländska gravhögarna vilade massakrerade danskar.

Det finns många varianter men ledmotivet är alltid att danska trupper överlistas och nedgörs av en här ledd av en småländsk kvinna. Vilket krig, vilken tid och vilken dansk kung det skedde under, finns det många bud om. Efter Rudbeck bearbetades legenden. Bråvalla hed fick kultstatus och sägnen användes för att förklara fornlämningar och samhällsföreteelser.

Legenden var runt 1820 mycket populär hos fornforskare. Det citerade utdraget från Magnus Bruzelius Swerges historia härrör från hans prisvinnande lärobok i historia som belönades av Svenska Akademien, i konkurrens med bland annat Erik Johan Stagnelius Liljor i Saron. Läroboken kom ut i flera upplagor och mängder av skolpojkar fick ta del av Bruzelius framställning om Blenda. Stagnelius skrev för övrigt ett längre diktepos om Blenda som trycktes postumt.

Bruzelius var verksam vid Lunds Universitet, men växlade över till antikvariska studier och blev adjunkt vid Historiska Museet. Bruzelius var förutom historieberättare en av dåtidens skickligaste antikvarier och det var han som myntade begreppet stenålder som en period definierad utifrån arkeologiska fynd efter det han hade grävt ut gånggriften Åsahögen utanför Helsingborg och en dös i Fjälkinge. ${ }^{9}$ Nilsson hade bidragit genom att bestämma djurbenen. Arkeologi och poesi låg nära varandra och både arkeologer och skalder intresserade sig för Blanda. Det är dock anmärkningsvärt att Bruzelius i sina antikvariska arbeten är strikt arkeologisk och sällan eller aldrig åberopar sagor för att tolka arkeologiska fynd, medan han i sina historiska arbeten broderar ut sagomotiv då han skriver om forntiden. Detta är en tidig indikation på hur arkeologi, historia och sagohistoria baserad på lingvistiska tolkningar, börjat gå skilda vägar.

Det fanns fler antikvarier som intresserade sig för Blendalegenden. Nils Henrik Sjöborg (1767-1838) hade varit professor i Historia vid Lunds universitet, men blev 1814 utnämnd till Antikvitetsintendent med uppsikt över landets alla fornlämningar. Sjöborg reste runt i provinserna och beskrev och ritade av fornlämningar. Givetvis var Blendalegendens platser högintressanta. Sjöborg daterade legenden inte till forntiden, utan till medeltiden, "första hälften af 1100 talet, eller till K. Sverker I:s regering" och det var den danske kungen Sven Grate som ledde danskarnas krigståg. Sjöborg ansåg andra dateringar otänkbara och gick hårt åt dem som menade att legenden härrörde från forntiden:

Det är ett löjligt tillägg i Sagan, att Blendas slag tilldragit sig för 3000 år tilbaka, hvilket tillhör den tid, då man ville börja Svenska Historien, om ej med Adam i Kjälkestad, åtminstone med syndafloden. ${ }^{10}$

Att Blendalegenden inte nämns hos den medeltida danske krönikören Saxo Grammaticus, huvudkällan för dansk 1100-talshistoria, förklarade Sjöborg genom enkel källkritik med: "[att] ingen undankommit, som kunnat berätta om nederlaget och omständigheterna dervid”. Blendalegendens äkthet kan man dock inte betvivla eftersom det är en av "Fornlemningar och gamla lagar ovanligt väl bestyrkt tradition”. Mängder med forn-

9 Nicklasson 2011

10 Sjöborg 1815, s 58f 
lämningar har fått namn efter fallna danska anförare som Tumling och Olof som ligger i två "stenrör”, rösen, norr om Dansjö: Kongsrör och Tumlinge rör. Blenda själv "lär hafva sin grafplats, antingen vid Wärnlanda, eller uti någon af grifterna vid Blädinge, rätteligen Blendinge”.

Den styrkta traditionen Sjöborg hänvisar till kan vara uppgifter Sjöborg bland annat hämtat från Linnés skånska resa under vilken Linné passerade Värend. ${ }^{11}$ Även Linné använde ortnamn för att belysa det historiska skeendet och berättade om dräktdetaljer och traditioner som vittnar om Blenda. Genom referenser till varandra kunde antikvarierna förstärka den historiska trovärdigheten hos en från början påhittad legend.

Sjöborg gav legenden en något underlig sensmoral då han konkluderade att:

Den som ej unnar det ofvananförda någon plats i Historien, kan tills vidare antaga Blendas folködande gästabud för ett slags karrikatur öfver det förderf för snille, arbetsdrift, helsa och kassa, som i läckraste välmening och af skönaste fåfänga tillskyndas våra kräsmagade herrar af Svenska kalassjuka Fruar. ${ }^{12}$

Sjöborg återvände 1822 till Blendalegenden i första tomen av sina Samlingar för Nordens Fornälskare, men tillförde knappast något nytt. Det mest intressanta är att han ritat av fornlämningsplatser på Blendas hed "en liten, men den vackraste del af slagfälten”. ${ }^{13}$ Bilden visar stensättningar, resta stenar och gravhögar i vilka det givetvis ligger klubbade danskar och Skatelöfs kyrka till höger. Till vänster ligger Sjöbo by, som genom ett av Sjöborgs många misstag, även den avbildats som kyrka.

Den östgötske antikvarien Johan Haquin Wallman (1792-1853) reste 1819 och 1822 genom Värend bland annat för att dokumentera Blendalegendens platser. Hans noggranna arbete finns bevarat i den magnifika handskriften Anteckningar öfver Gamla Fylkeslandet Verends Historia och Fornlemningar. Wallman lyckades bland annat lokalisera Blendas gravhög i Värnlanda (se fig. 1, nästa sida), en smått enastående prestation om man betänker att berättelsen är påhittad.

Alla de uppräknade antikvarierna var medlemmar i det Götiska förbundet, en sammanslutning som tagit som sin uppgift att återuppliva den götiska andan och där medlemmarna hade en skyldighet att bedriva fornforskning. Förbundets starke man var skriftvårdare Jacob Adlerbeth (1785-1844) som år 1821 hälsade på Esaias Tegnér i Lund. Adlerbeth och Tegnér kom överens om att det fanns ett akut behov av en svensk nationalsång och söp ihop sig så rejält att Tegnér blev sängliggande över en månad med leverinflammation. På hemvägen passerade Adlerbeth genom Värend och han kom fram till att Blendalegenden var det givna ämnet för nationalsången. Tyvärr backade Tegnér ur då han nyktrat till och de götiska planerna gick i stöpet. Han ansåg att: "En flicka, som super fienderna fulla och sedan mördar dem i sömnen, är ingen poetisk person" och passade inte som ämne i en nationalsång. ${ }^{14}$ Det Värend Nilsson reste genom på väg norrut

\footnotetext{
11 Linné 1959, s. 63f, 74

12 Sjöborg 1815, s. $63 f$

13 Sjöborg 1822, s. 113

14 Tegnér till Adlerbeth 24 augusti 1822. Citerat i: Tegnér, 1954, s. 277. För arbetet med göternas nationalsång se Nicklasson 2014b (In press)
} 


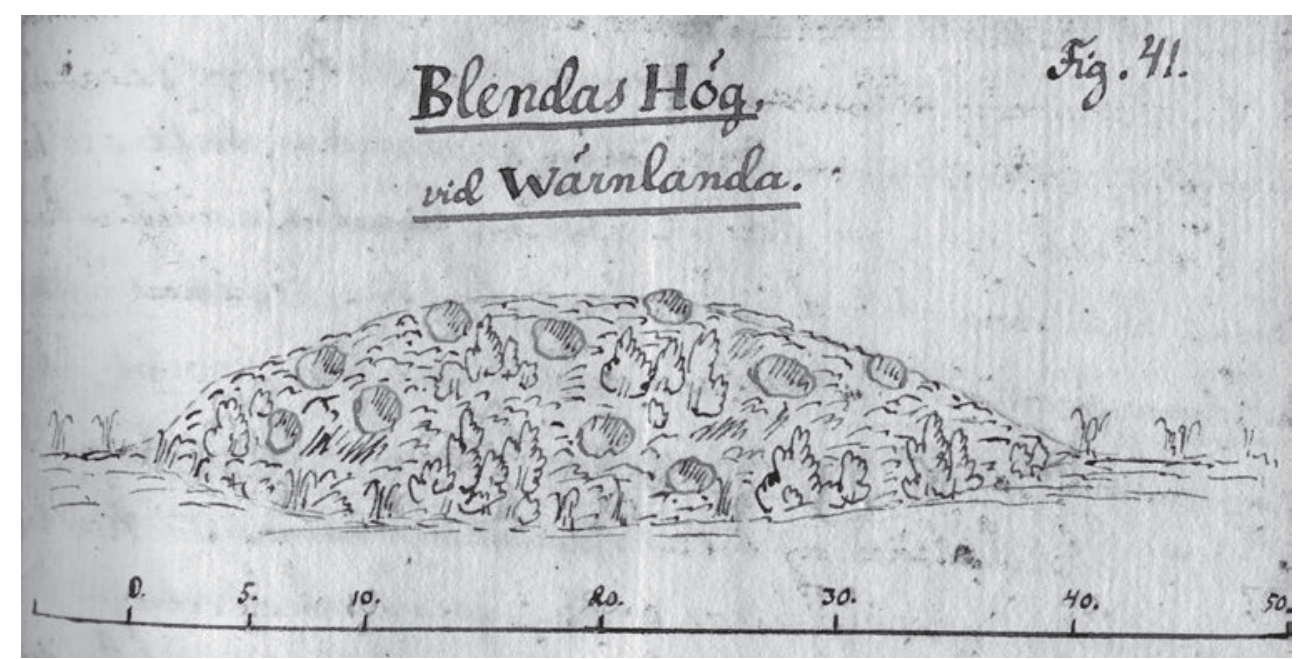

Fig. 1. Blendas gravhög i Värnlanda ritad av Johan Haquin Wallman under resor $i$ Värend 1819 och 1822. Bild: ATA.

genom Sverige var en trakt fylld av legender och antikvarier på spaning efter en mer eller mindre autentisk forntid.

\section{Nilsson i Värend}

Nilssons resejournal förvaras numera i Lunds Universitetsbilbiotek och har signum C5 i Sven Nilssons samling. Nilsson skrev ibland sina dagböcker snabbt och förkortade ord och hela meningar i ett slags personlig stenografi, vilket gör dem delvis svårlästa. Skåningen Nilsson uppskattade inte mörka Småland:

Dessa eviga barrskogarna som knappt tilläto ögat skåda hundrade steg kring sig, och som nästan endast afbrötos af fula med ved kolade stubbar och stenar beströdda backar, eller af en svedja eller en ful Myr, blefvo slutligen grufligen tråkiga och mättande för den som var van att se en vid horisont

Först när landskapet öppnades upp i Värend blev Nilsson på bättre humör. De gästvänligare bygderna hyste också fler synliga fornlämningar och monument från forntiden och det var nu Nilsson började fundera i antikvariska och lingvistiska banor:

Här är den märkvärdigaste trakt af Småland. Här tros bråvalla slag ha stått, och här är valplatsen för den märkvärdiga Blendas qvinnohär. Denna händelse stiga så långt tillbaka i den gråa ålderdomen, att den visar sig som half historia, half fabel. Också vore anledning att tro hela historien vara dikt och alla namnen symboliska om ej den omständighet motsade det att systrarna här ärfva lika med bröderna, att de ha rättighet att vid bröllop och andra högtidligheter bruka trummor och pukor, att qvinnorna i Östby Härad, som gränsar intill, betala springskatt. Nämde fördelar ha almogens qvinnor i Albo, Norrvidinge, Upvidinge och Hånga Härader.

Nilsson återberättar därefter en kortversion av Blendalegenden i dagboken och hänvisar till Sjöborgs Uppgift som källa. Han reflekterade över de många ortnamn som med större eller mindre rätt går att knyta till legenden. "Vid Benestad skulle de flesta ha stupat och deras ben länge der legat obegrafna [...] Vid Dansjö=Danskarnas sjö, finnes ett ofantligt 


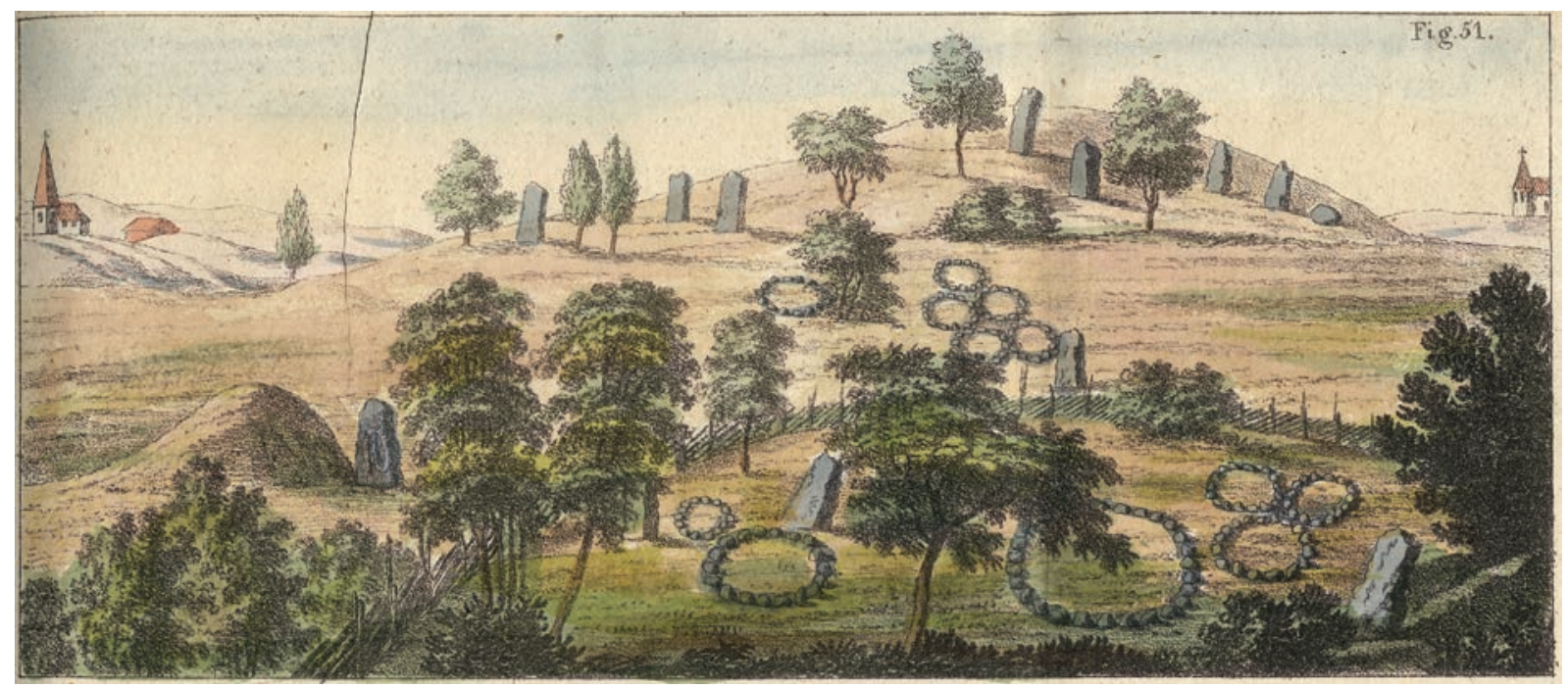

Fig. 2. Blendas hed enligt Nils Henrik Sjöborg. I de många fornlämningarna vilar ihjälslagna danskar. Sjöborg var ingen noggrann antikvarie och Sjöbo by till vänster har han råkat avbilda som en kyrka. Från Sjöborg 1822. Bild: LUB Media.

stenrör i hket Sjöborg tror att Tumlingen ligger begrafven.” Tumlingen var namnet på en av danskarnas anförare som de småländska damerna klubbade ihjäl.

NB Alla namn synas mig allt för symboliska för att bevisa något för sagans historiska sanning. Snarare bevisa de för dess roman-halt. Blända=förblinda=hon förblindar nämde fiender med mjöd och kärlek; Tumlinge af tumla=falla. Det var fienden som föll. Om det ej vore en forntidens roman h[vi]ken man här i trakten velat ge lif och verklighet, hade väl knapt så många symboliska namn uppko[mm]it som alla de nämda. Kan ej de[nn]a krigsroman sättas vid sidan af Signilds och Haborgs kärleksroman, h[vi]ken man ej blott på ett utan på 4 à 5 särkilta ställen ge[n]o[m] namn och minnesmärken velat ge verklighet.

Med symboliska avser Nilsson snarast att ortnamnen är påhittade och Nilsson är skeptisk till den historiska sanningshalten bakom inte bara Blendalegenden utan forntida legender i allmänhet. Signilds och Haborgs kärleksroman är ett annat forntidsepos som bland annat knutits till Asigetrakten i Halland med monumentala fornlämningar som Haborgs galge och Signilds bur som synliga bevis. Nilsson hade några år tidigare besökt Halland och beskådat dessa lämningar. ${ }^{15}$ Legenden hade förutom till Halland lokaliserats till Själland och Sigtunatrakten. Då Nilsson reste i Halland hade han skrivit ner legenden och inte riktat några invändningar mot fornlämningarnas sagohistoriska anknytning.

Det är intressant att jämföra Nilssons skeptiska dagboksanteckningar med vad hans skrev till två av sina gynnare, Lars von Engeström och biskop Wilhelm Faxe. Nilsson visste att dessa var intresserade av forntiden och anpassade säkert sina brev därefter. Engeström var vid det här laget gammal och smått senil, men hade varit drivande i Vitterhetsakademien, den myndighet som närmast handlade fornvårdsärenden och varit den som sett till att Sjöborg blev utnämnd till Antikvitetsintendent och givetvis Nilssons utnämning till professor. Faxe var inte på samma sätt aktiv som fornforskare, men han gjorde sitt bästa för att freda skånska fornlämningar. Biskopen berättade för Götiska för-

15 Nicklasson 2014a 
bundets starke man, Jacob Adlerbeth att "han för 14 år sedan genom maktspråk räddat ett forntidsminnesmärke kändt under namn af konung Haralds graf, till hvars fredande från förstöring han genom föreställningar förgäfves öfvertala allmogen. Då Biskopen yttrat att K. Harald der legat i 1000 år hade en af bönderne svarat: då har den gamle skälmen legat der länge nog.” ${ }^{16}$ Det var inte lätt att freda fornlämningar i början av 1800-talet!

Nilsson skrev två nästan identiska brev till Engeström och Faxe från Värend. Till Faxe skrev han:

Här är den, i antiqwariskt afseende märkvärdigaste trakt i hela Småland. Här tros Bråwalla slag ha stått, och här är stället der den märkwärdiga Blendas qwinnohär slog Danskarna. Ännu lefwer händelsen genom tradition hos allmogen i wissa plägseder och bruk i wissa rättigheter för qwinnokönet, och i belysningsfulla namn på ställen. Lästad war Danskarnas lägerstad då de blefwo angripna. Vid Ströby blefwo de skingrade. Vid Bläinge (Blendinge=Blendas by) finnas många stora stenkummel, af hwilka det största kallas Tumlinge rör under hvilket Danskarnas anförare Tumlingen säges ligga begrafwen. Benestad skall ha sitt namn deraf att de flesta Danskar der föllo och deras ben blefwo obegrafna liggande på marken. Händelsen stiger så långt tillbaka i den gråa, tökniga ålderdomen, att man ej kan med wisshet utmärka tiden då den inträffade. ${ }^{17}$

Man känner igen formuleringar från dagboken, men Nilsson uttryckte inga tvivel om Blendalegendens äkthet eller sina källkritiska funderingar om att ortnamn som knutits till sagan skulle vara symboliska, det vill säga påhittade. Han var taktiskt medveten och det hade varit oklokt att ifrågasätta den sagohistoriska verklighet som hans välgörare trodde på. Man får av breven intryck av att Nilsson sett några av de fornlämningar som knöts till legenden, även om detta inte nämns i dagboken. Nilssons olika åsikter i dagbok och brev visar på ett problem då man forskar om äldre tiders antikvarier. I privata anteckningar och brev till nära förtrogna kan de uttrycka en syn på forntiden och vara kritiska till gängse tolkningar, medan de i publikationer och andra handlingar går på en annan linje som tillfredsställde läsare och sponsorer. Det är ibland inte helt lätt att bedöma vad antikvarierna ansåg och hur stor kunskap om forntiden de egentligen besatt.

\section{En forntid i gungning?}

Hur ska man förstå Nilssons kritik av lingvistik som antikvarisk metod? Lingvistik hade använts av antikvarier sedan antiken för att spåra forntida folk och dra långtgående kulturhistoriska slutsatser och metoden att para ihop ytliga namnlikheter ansågs ha stor trovärdighet. Runt år 1800 började man emellertid studera språk systematiskt och grammatiskt och kunde med nya vetenskapliga metoder inom lingvistiken avfärda ytliga språkliga likheter som kulturhistoriska källor. Hade Nilsson redan 1821 börjat tänka i nya banor som ledde till att han ett drygt decennium senare förnyade arkeologin?

16 UUB Adlerbeths dagbok 18 augusti 1821

17 LUB Nilsson till Faxe 14 juli 1821 snarlika uppgifter i: KB Nilsson till Engeström 26 juli 1821 
Både ja och nej. Det är viktigt att komma ihåg att Nilsson närmade sig arkeologin som naturforskare, vilket ger en nyckel till hur han uppfattade fornsagor. Genom den nya vetenskapen geologi fick Nilsson steg för steg insikt att jordens historia måste vara betydligt äldre än de få årtusenden man hade räknat fram genom att studera Bibeln. Man hade inga möjligheter att datera formationer absolut, men genom att identifiera de geologiska processer som skapat dem, drog man slutsatsen att lagren måste ha bildats under enorma tidsrymder. I en uppsats från 1835 om svenska fynd av dinosauriefossil, kopplar Nilsson samman dessa insikter med den mänskliga historien:

Mellan den dag den sista Plesiosaurus dog, och den, då den första menniskan vaknade till lif, ligger en hel organisk verld utdöd i tertiärformationen. Kan denna tidrymd mätas med årtusenden eller med årmillioner! Och dock utgör den en obetydlighet mot den tidsström, som förrunnit, sedan Trilobiter och Orthoceratiter hade lif. ${ }^{18}$

Nilsson är ovanligt rättfram då han länkade den mänskliga historien till jordens geologiska historia som visar hur Nilsson menade att arkeologi måste bedrivas som naturvetenskap. Hans årmiljoner var mycket vågade och ifrågasatte åtminstone delar av den bibliska skapelseberättelsen. Många geologer duckade av religiösa skäl att spekulera om hur gamla lager och fossil är och gjorde sitt yttersta för att få sina fynd att stämma överens med Bibelns uppgifter. Utan några möjligheter till att datera sina fynd absolut har Nilsson förbluffande mycket rätt i sina förmodanden om dinosauriernas ålder. En av de saker som ansågs mest uppseendeväckande med Nilssons arkeologiska publikationer på 1830-talet var att han förlängde forntiden med flera sekler och fick på så sätt plats med ett vildestadium, det vi kallar stenåldern. Några sekler hit och dit är en petitess för en nutida arkeolog, men det innebar att man plötsligt hade en forntid som inte nämns i några skriftliga källor och det bibliska ramverket spricker. Nilsson deltog sålunda i att skapa en förhistoria.

År 1821 måste Nilsson åtminstone ha anat att jordens ålder var högre än man tidigare hade anat. Detta kan ha lett honom att reflektera över den mänskliga historien och att denna måste vara äldre än de några tusen år som Sjöborg och andra humanistiskt skolade antikvarier antog. Dessa aningar kan ha fått Nilsson att börja misstro "forntidsromanerna” och det nordiska sagostoffet. Fornlämningar måste vara äldre än sagorna.

Å andra sidan var Nilsson absolut inte främmande för att själv använda intrikata lingvistiska argument. I sin mest famösa teori, att norra och västra Europa hade koloniserats av fenicier under bronsålder, använde sig Nilsson flitigt av klassiska ytliga namnlikheter. Solguden Baal hade överlevt i den nordiske guden Balder och hade dyrkats på platser som Balsberget och det feniciska arvet levde kvar i folkkulturen. Nilsson hade i sin ungdom dansat runt Balsbål för att hälsa våren och sig själv ovetande, dyrkat den feniciske Baal. I sitt sista antikvariska arbete från 1877 drog sig Nilsson till minnes att han för sjuttio år sedan jagat på en ödslig hed som kallades Cimbremarken, ${ }^{19}$ ett starkt belägg

18 Nilsson 1835, s. 140

19 Nilsson 1877 
för att cimbrer, ett folk som Nilsson insett var besläktat med fenicierna, hade koloniserat Skåne. År 1877 hade arkeologin knoppats av från den gamla antikvarianismen och blivit en disciplin med egna metoder och synsätt. Inga av Nilssons yngre kollegor trodde på honom och hans fenicier möttes med förintande kritik. Ytliga lingvistiska likheter sågs som en anakronistisk och ovetenskaplig kvarleva från förlegad antikvarianism.

Det är därför nog mer korrekt att uppfatta Nilssons kritiska anmärkningar mot Blendalegenden 1821 mer som en kritik mot den fornnordiska sagohistorien än mot lingvistiken som metod. Nilsson kom som arkeolog att bli starkt skeptisk mot nationell historieskrivning och var totalt ointresserad av den järnåldersvärld som beskrivs i de isländska sagorna och i bästa fall i sagor som de om Blenda och Hagbard och Signe. Han kallade de krigiska svearnas hårda livsföring för "orgier och kasernlif” och i ett brevutkast till Bernhard von Beskow beskrev han deras dekadens: ”I deras Walhalla fördes egentligen ett (riktigt) Kasernlif: att dricka, slåss och uppassas af vackra tärnor, deri bestod deras himmel till hvilken de sväfvade och hvarom de voro säkra om de läto slå ihjäl sig på slagfältet.”20

Man ska inte se detta som ett avståndstagande från de skriftliga källorna och en arkeologi som strävade efter att "få fynden att tala av sig själva”, på det sätt nutida arkeologi stundom presenterar sitt ämne. Nilsson använde sig tvärtom av stora mängder skriftliga källor och extrem närläsning för att belägga sin fenicierteori. Genom dessa kunde han länka Sydskandinavien till Medelhavsområdet och bevisa att fenicierna gett Norden civilisationens ljus. Pyteas från Massila, Strabon och Pomponius Mela ersatte Snorre, Saxo och Petter Rudbeck som källor för den nordiska forntiden.

Även om man inte kan spåra något djupare intresse för forntiden i Nilssons resejournal från 1821 och inte direkt kan koppla den till hans arkeologiska skrifter från 1830-talet, innehåller den tanketrådar och inblickar i Nilssons föreställningsvärld som gör det lättare att förstå både hans omdaning av arkeologin och hans kuriösa idéer om forntiden. Arkeologi, lingvistik och närläsning av skriftliga källor var under Nilssons tid alltjämt förenade och studiet bedrevs av antikvarier som använde sig av detta breda källmaterial och sekelgamla humanistiska traditioner för att forska om forntiden. Nilsson närmade sig arkeologin som naturforskare, tillförde nya perspektiv och plockade ut de delar av antikvarianismen som passade hans sätt att forska. Så blandades nytt och gammalt, det revolutionerande och det förlegade.

\section{Referenser}

\section{Otryckta källor}

\section{Antikvariskt-topografiska Arkivet (ATA)}

Wallman, Johan Haquin. 1823. Anteckningar öfver Gamla Fylkeslandet Verends Historia och Fornlemningar, samlade under Resor igenom Provinsen, åren 1819, 1822. 1sta Häftet, Landets Historia och Hedniska Fornlemningar. Concept - Utkast.

20 LUB C29 p. 11f utkast till brev till von Beskow. Brevet aldrig skickat 


\section{Kungliga Biblioteket (KB)}

Brev från Sven Nilsson till Lars von Engeström

\section{Lunds Universitetsbibliotek (LUB)}

Nilssons samling volym C5, C29

Brev från Sven Nilsson till Wilhelm Faxe

\section{Uppsala Universitetsbibliotek}

Jacob Adlerbeths dagbok

\section{Litteratur}

Bruzelius, Magnus (1821), Swerges historia för Ungdom. Andra Afdelningen Medeltiden eller Catholska Tidehvarfwet. Lund: Berlingska Boktryckeriet.

Linné, Carl von (1959), Carl Linncei Skånska Resa: På Höga Överhetens Befallning Förrättad År 1749: Med Rön Och Anmärkningar Uti Ekonomien, Naturalier, Antikviteter, Seder, Levnadssätt: Med Tillhörige Figurer. Stockholm: Wahlström \& Widstrand.

Nicklasson, Påvel (2011), "Magnus Bruzelius, Jacob Adlerbeth and the Invention of the Stone Age". LAR Vol. 17: 61-83.

Nicklasson, Påvel (2014a), "Antikvariska uppgifter i Sven Nilssons resejournal från Halland 1814". Ale. Nr 1:14-21.

Nicklasson, Påvel (2014b) (In press), Göternas folksång.

Nilsson, Sven (1835), Skandinavisk Fauna Foglarna. Ny omarbetad upplaga. Lund.

Nilsson, Sven (1835b), "Fossila amfibier funna i Skåne". Kongl. Vetenskapsacademiens Handlingar.

Nilsson, Sven (1838-1843), Skandinaviska nordens ur-invånare ett försök i komparativa ethnografien och ett bidrag till menniskoslägtets utvecklingshistoria. Lund.

Nilsson, Sven (1877), "Om Amuletter. Föredrag i de skånska landskapens historiska och arkeologiska förening”. Samlingar utgifna för de skånska landskapens historiska och arkeologiska förening VI: 1-6.

Regnéll, Gerhard (red. 1983a), Sven Nilsson En lärd i 1800-talets Lund. Studier utgivna av Kungl. Fysiografiska Sällskapet i Lund. Lund.

Regnéll, Gerhard (1983b), "Zoologen och arkeologen som var geolog”. I Sven Nilsson En lärd i 1800-talets Lund, 23-83. Studier utgivna av Kungl. Fysiografiska Sällskapet i Lund. Lund.

Sjöborg, Nils Henrik (1815), Uppgift på fornlemningars kännetecken. Stockholm.

Sjöborg, Nils Henrik (1822), Samlingar för Nordens fornälskare. Första tomen. Stockholm. Tegnér, Esaias (1954), Esaias Tegnérs Brev. II 1818-1823. Redaktör: Palmborg, Nils. Malmö: Tegnérsamfundet/Allhem.

Trofast, Jan, red. (2002), Brevväxlingen mellan Herr Professoren Jac. Berzelius och Hans Excellens H. G. Trolle Wachtmeister. I. Lund: Utgiven av Berzelius-sällskapet. 